\title{
Transplant Age Has Little Influence on Yield of Muskmelon (Cucumis melo L.)
}

\section{D.S. NeSmith \\ Department of Horticulture, The University of Georgia, Georgia Station, Griffin, GA 30223-1797}

Transplants are used extensively in the southeastern United States for vegetable crops, including muskmelon. Transplant age is important because growers often contract to receive transplants at a specific time and the performance of older transplants is uncertain. The relationship between transplant age and yield in several crops is not clear (Kratky et al., 1982; Lamont, 1992; Leskovar et al., 1991; McCraw and Greig, 1986; Weston, 1988; Weston and Zandstra, 1989). Recently, research with squash (Cucurbita pepo L.) (NeSmith, 1993) and watermelon [Citrullus lanatus (Thunb.) Matsum. \& Nakai] (Vavrina et al., 1993) indicated that transplant age had no influence on early and total yields of these cucurbit crops. The objective of this research was to examine the influence of transplant age on muskmelon yield.

'Cordele' muskmelon transplants of varying ages were grown in field experiments during 1992 and 1993 at the Georgia Station Horticultural Research Farm in Griffin. Transplants for both years were grown in $50-\mathrm{cm}^{3}$ cells containing a commercial growing medium (Metro-Mix 300; W.R. Grace and Co., Cambridge, Mass.). Single seeds were planted in cells at different times so that transplants of designated ages $(2,4,6$, and 8 weeks old $)$ were available for planting in the field on a common date. The transplants were watered daily and fertilized three times weekly with a solution of commercial fertilizer $(20 \mathrm{~N}-8.8 \mathrm{P}-16.6 \mathrm{~K}$ plus micronutrients at a concentration of $200 \mathrm{ppm}$ N; Peters Professional General Purpose Fertilizer, W.R. Grace and Co.). Minima and maxima in the greenhouse for transplant production were 20 to $21 \mathrm{C}$ and 25 to $30 \mathrm{C}$. Only natural light was used, and its transmission into the greenhouse was $\approx 70 \%$ of sunlight.

On 4 May 1992 and 27 Apr. 1993, transplants of all ages were hand-planted to a Cecil sandy clay loam (clayey, kaolinitic, Thermic Typic Hapludult) soil. Also included in the 1993 experiment was a direct-seeded treatment for comparison. Rows were $1.5 \mathrm{~m}$ apart,

Received for publication 25 Oct. 1993. Accepted for publication 26 Feb. 1994. A contribution of the Univ. of Georgia Agricultural Experiment Station, Georgia Station, Griffin. This research was supported by state and Hatch Act funds. The cost of publishing this paper was defrayed in part by the payment of page charges. Under postal regulations, this paper therefore must be hereby marked advertisement solely to indicate this fact. and within-row plant spacing was $90 \mathrm{~cm}$. Treatments were arranged in a randomized complete-block design with three replications. Each experimental unit was five rows wide by $13.9 \mathrm{~m}$ long. Fertilizer and pesticides were applied according to standard recommendations, and overhead sprinkler irrigation was used to supplement rainfall.

A subsample of plants was taken the day of transplanting each year to determine leaf count, vine length, and shoot dry weight of the various transplant ages. Shoot dry weight was determined after oven-drying at $60 \mathrm{C}$ for $72 \mathrm{~h}$. Yields were determined by harvesting the center three rows of each plot during six harvests each year. At each harvest, individual fruit were weighed and enumerated. Single degree of freedom contrasts were conducted for linear and quadratic effects of transplant age on yield at each harvest interval. An orthogonal contrast was used in 1993 to compare the yields of the seeded control to that of all transplants.

At the time of transplanting, differences in growth and development of the various-aged transplants were substantial. Mean leaf counts per plant, along with standard errors, were 3.8 $\pm 0.2,6.4 \pm 0.2,9.6 \pm 0.2$, and $11.8 \pm 0.2$ for 2-, 4-, 6-, and 8-week-old plants, respectively. Vine lengths at transplanting during 1993 averaged $7.5 \pm 0.4,19.6 \pm 0.8,34.8 \pm 1.1$, and $48.0 \pm 1.6 \mathrm{~cm}$ for the $2-, 4-, 6-$, and 8 -week-old transplants, respectively. Shoot dry weight during 1993 averaged $0.1 \pm 0.0,0.8 \pm 0.1,1.4$ \pm 0.2 , and $1.6 \pm 0.1 \mathrm{~g} / \mathrm{plant}$ for the $2-, 4-, 6-$, and 8-week-old plants, respectively. The 6- and 8week-old transplants had started to flower by the time of transplanting each year.

Despite growth and developmental differences among transplants at planting, transplant age had little effect on early or total yield of muskmelon as indicated by cumulative 1992 and 1993 yield data (Fig. 1). However, transplants of all ages produced a significantly $(P \leq$ $0.05)$ earlier yield than the seeded control during 1993. Yields overall were higher during 1993 than in 1992. Fruit counts per unit land area (mean of 12,906 and 21,760 fruit/ha in 1992 and 1993, respectively) and individual fruit weight (mean of $2.8 \mathrm{~kg} /$ fruit both years) were similar among the various transplant ages.

These results agree with those for squash (NeSmith, 1993) and watermelon (Vavrina et al., 1993) and indicate that transplant age at planting (within reason) does not influence

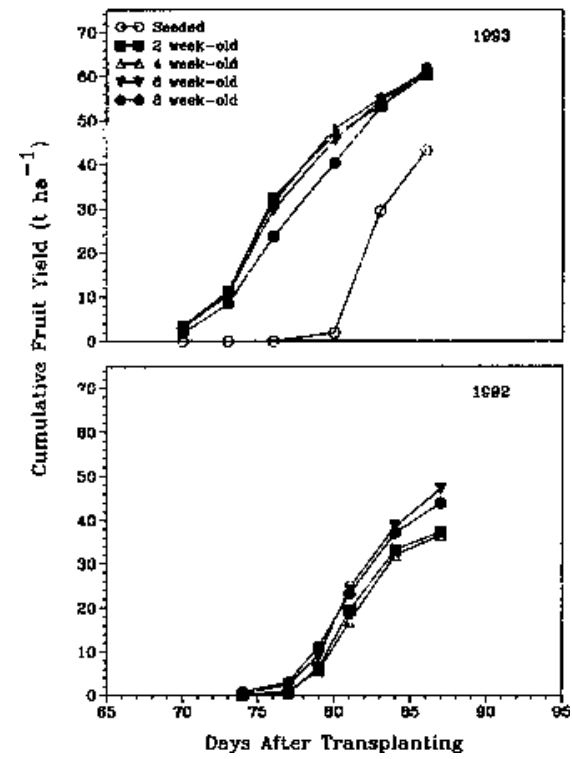

Fig. 1. Mean cumulative yields resulting from 2-, 4-, 6-, and 8-week-old muskmelon transplants and a direct-seeded control (1993 only).

muskmelon yield. However, transplants generally produce earlier yields than seeded crops planted on the same date in the field. These data suggest that growers can hold transplants when adverse weather does not permit planting. Moreover, because young transplants performed satisfactorily, the additional growing time and energy costs associated with older transplants can likely be saved. Transplants must not be so young and succulent that they would be damaged by mechanical transplanting. Conversely, transplants must not have excessive vine growth, which could also present difficulty in mechanical planting.

\section{Literature Cited}

Kratky, B.A., J.K. Wang, and K. Kubojiri. 1982. Effects of container size, transplant age, and plant spacing on Chinese cabbage. J. Amer. Soc. Hort. Sci. 107:345-347.

Lamont, W.J. 1992. Transplant age has little effect on broccoli head weight and diameter. HortScience 27:848

Leskovar, D.I., D.J. Cantliffe, and P.J. Stoffella. 1991. Growth and yield of tomato plants in response to age of transplants. J. Amer. Soc. Hort. Sci. 116:416-420.

McCraw, B.D. and J.K. Greig. 1986. Effect of transplant age and pruning procedure on yield and fruit-set of bell pepper. HortScience 21:430431.

NeSmith, D.S. 1993. Transplant age influences summer squash growth and yield. HortScience 28:618-620.

Vavrina, C.S, S. Olson, and J.A. Cornell. 1993. Watermelon transplant age: Influence on fruit yield. HortScience 28:789-790.

Weston, L.A. 1988. Effect of flat cell size, transplant age, and production site on growth and yield of pepper transplants. HortScience 23:709-711.

Weston, L.A. and B.H. Zandstra. 1989. Transplant age and $\mathrm{N}$ and $\mathrm{P}$ nutrition effects on growth and yield of tomatoes. HortScience 24:88-90. 